\title{
Effect of Interleukin-1 $\beta$ on Plasma ACTH, $\beta$-Endorphin, and Corticosterone Levels in Infant and Prepubertal Rats
}

\author{
ISTVÁN BARNA, ZSUZSANNA ÁCS, GYULA BUGOVICS, AND JAMES I. KOENIG \\ Institute of Experimental Medicine, Hungarian Academy of Sciences, H-1450 Budapest, Hungary \\ [I.B., Z.Á.], Institute for Drug Research, H-1325 Budapest, Hungary [G.B], and National Science \\ Foundation, Division of Integrative Biology and Neuroscience, Arlington, Virginia 22230 [J.I.K.]
}

\section{ABSTRACT}

IL- $1 \beta$ is known to enhance ACTH release from the anterior pituitary in the adult rat, mainly by simulating the hypothalamic ACTH-releasing hormone (CRH) release, but it seems to have a direct effect on the pituitary and on the adrenal hormone secretion, too. The effect of IL- $1 \beta$ on the $\beta$-endorphin $(\beta \mathrm{E})$ secretion from the intermediate lobe is less well studied. There is very little information on the effect of IL- $1 \beta$ on the hypothalamic-pituitaryadrenal axis (HPAA) in the postnatal rat, which is a special period, because the reactivity of the HPAA is blunted. The effect of IL- $1 \beta$ in this period seemed to be of special interest, because neither the immune nor the endocrine system is fully developed. In the present study we tested the 30- and 120-min effect of intraperitoneally administered 0.5 and $100 \mathrm{ng} / \mathrm{g}$ body weight IL- $1 \beta$ on the plasma immunoreactive (ir) ACTH, $\beta \mathrm{E}$, and corticosterone (CS) levels in the 10-d-old (infant) and 30-d-old (prepubertal) rat. Generally, the ir- $\mathrm{ACTH}$, ir- $\beta \mathrm{E}$, and ir-CS levels were significantly higher in prepubertal than in infant rats. Hormone levels were more enhanced by the higher dose of IL- $1 \beta$, and changes were more pronounced at 120 min than at 30 $\min$. The relative increase of ir-ACTH and ir- $\beta \mathrm{E}$ was smaller in the infant than in the prepubertal rat. In contrast, the relative increase of ir-CS was more pronounced in the infant rat. Changes in plasma ir- $\beta \mathrm{E}$ and ir-ACTH levels were not parallel, suggesting different responsiveness of the anterior pituitary corticotrophs and intermediate pituitary melanotrophs to IL- $1 \beta$ stimulation. The age-related peculiarities in response to IL- $1 \beta$ could be due to a different secretory capacity and/or different kinetics of the HPAA in the infant (10-d-old) and prepubertal (30-d-old) rat. There could be a change in sensitivity of different components of the HPAA (hypothalamus, pituitary, adrenal) to IL- $1 \beta$ during the postnatal development. (Pediatr Res 37: 714-719, 1995)
Abbreviations
CRH, ACTH-releasing factor
$\boldsymbol{\beta E}, \beta$-endorphin
CS, corticosterone
ir, immunoreactive
HPAA, hypothalamic-pituitary-adrenal axis i.p., intraperitoneally

IL- $1 \beta$ is a $17,500-\mathrm{D}$ hormone-like polypeptide synthesized and released predominantly by macrophages and monocytes. It acts as a primary mediator in the acute phase of the response to microbial infection and physical stressors $(1,2)$. In addition to its role in the host defense mechanism, a growing body of evidence has accumulated indicating that IL-1 $\beta$ is a putative mediator between the immune and neuroendocrine systems (3-10). Interactions between the immune system and the HPAA are of particular interest, because they are both associated in the adaptive response to stress. The main target of the IL- $1 \beta$ effect on the HPAA is believed to be the stimulation of

Received July 12, 1994; accepted December 19, 1994

Correspondence: István Barna, Institute of Experimental Medicine, Hungarian Academy of Sciences, H-1450 Budapest, P.O. Box 67, Hungary.

Supported by Hungarian Scientific Research Foundation grant 2922. ACTH 1-39 $_{\text {stan- }}$ dard was kindly provided by NIH National Institute of Diabetes and Digestive and Kidney Diseases.
CRH secretion (11-13), but it has been shown to exert a direct effect on the pituitary and on adrenal hormone secretion as well $(14,15)$. It is to be elucidated if activation of the HPAA by IL- $1 \beta$ is a specific effect or if it represents a nonspecific stress reaction.

In the neonatal rat responsiveness of the HPAA to stressful stimuli is reduced. During this stress-hyporesponsive period, the ACTH response to a variety of nonspecific stressors as ether inhalation or electroshock $(16,17)$, hypoglycemia $(18)$, histamine, and cold (19) is blunted. Additionally, after cold or ether stress plasma $\beta E$ levels were unchanged in the 10 -d-old but enhanced in older rats (20). In contrast, plasma $\beta E$ levels of the 10-d-old rats were considerably increased after the specific stimulus of an opiate anesthetic (21).

Whereas the effect of IL- $1 \beta$ on the HPAA in the adult rat is extensively studied, we are aware of only one study on the effect of IL-1 $\beta$ on the HPAA of the prepubertal rat; the HPAA 
reactivity of the infant rat (less than $20 \mathrm{~d}$ old) has not been studied. In addition we do not know of any data testing the effect of IL- $1 \beta$ on plasma ir-ACTH, ir-CS, and ir- $\beta$ E levels simultaneously, neither in adult nor in infant or in prepubertal rats. In a recent study (22) a dose-dependent elevation in plasma ACTH and CS concentrations was found in immature (21-22 d old) rats after $0.5-2.0 \mathrm{ng} / \mathrm{g}$ IL- $1 \beta$ i.p. Inasmuch as IL- $1 \beta$ is considered as a specific mediator between the immune system and the HPAA $(8-10)$, the comparison of the effect of IL- $1 \beta$ on the activity of HPAA in the 10-d-old (infant) and in the 30 -d-old prepubertal (postweaning) rat could discriminate between the possible specific and nonspecific component of the activation of the HPAA by IL- $1 \beta$.

\section{METHODS}

Animals. Wistar rats of our inbred colony were kept under standard laboratory conditions: $12-12-\mathrm{h}$ light-dark cycle, $23 \pm$ $2^{\circ} \mathrm{C}$ room temperature, commercial rat food, and fresh tap water ad libitum. They were bred in pairs, and the morning on which pups were found in the cage was considered the first postnatal day. Litter size was reduced to 10 , and the pups were weaned on the 22nd postnatal day. The 10-d-old pups of either sex were left with the parent rats until the end of the experiment. The 30-d-old male rats, kept three per cage, were handled daily for $1 \mathrm{wk}$ before the experiment. Both 10- and 30 -d-old rats were weighed and labeled the day before the experiment.

Experimental design. Both in the 10- and in the 30-d-old rats the effect of 0.5 and $100 \mathrm{ng} / \mathrm{g}$ body weight $/ 1 \mu \mathrm{L} \mathrm{IL-} 1 \beta$ was tested 30 and $120 \mathrm{~min}$ after i.p. injection. Untreated rats, subjected to handling, and saline-treated rats (physiologic saline, $1 \mu \mathrm{L} / \mathrm{g}$ body weight i.p.) corresponding to the time schedule of the given experiment served as controls. In one experiment the response to one dose of IL- $1 \beta(0.5$ or $100 \mathrm{ng} / \mathrm{g}$ body weight) at one time point (30 or $120 \mathrm{~min}$ ) was tested either in 10- or in 30-d-old rats with the corresponding control groups. Experiments were performed between 0900 and 1100 h. Treatments were given according to a randomized block design using 50- or $100-\mu \mathrm{L}$ Hamilton syringes. After injection, rats were returned immediately to their mother or their home cage, respectively.

$\boldsymbol{I L}-\boldsymbol{I} \boldsymbol{\beta}$. The human recombinant IL- $1 \beta$ we used in this study was expressed in the Escherichia coli strain JM 103 as soluble protein. The expression vector (human macrophage origin cDNA coding the sequence of IL- $1 \beta$ cloned into the M7/11 vector) was a generous gift of Prof. T. Bártfai (University of Stockholm, Sweden). The crude IL- $1 \beta$ extract was further purified to homogeneity according to Wingfield $e$ al . (23). The specific bioactivity determined by the thymocyte-activating factor assay was $1.4 \times 10^{7} \mathrm{U} / \mathrm{mL}$, and the endotoxin contamination detected by the Limulus amebocyte lysate chromogenic assay was less than 0.75 endoxin unit $/ \mathrm{mL}$.

Sample collection and hormone measurements. Thitty or $120 \mathrm{~min}$ after the treatments, animals were decapitated, and the trunk blood was collected on ice into Eppendorf tubes containing an appropriate volume of $20 \% \mathrm{~K}_{2}$-EDTA. Blood was centrifuged and stored at $-20^{\circ} \mathrm{C}$ until assayed. Plasma hor- mone levels (ir-ACTH, ir- $\beta \mathrm{E}$, and ir-CS) were determined by RIA without extraction as described previously $(21,24)$. The ACTH antibody was used in 1:150,000 final dilution, total bound was $30 \%$, nonspecific binding $1.7 \%$, and the $\mathrm{ED}_{50} 1.5$ $\mathrm{fmol} \mathrm{ACTH} /$ tube. Final dilution of the ir- $\beta \mathrm{E}$ antibody was $1: 120,000$, the total bound was $30 \%$, nonspecific binding $1.7 \%$, the $\mathrm{ED}_{50} 5.8 \mathrm{fmol} \beta \mathrm{E} /$ tube. In our CS RIA (final antibody dilution 1:8000) total bound was $45 \%$, nonspecific binding $14 \%$ and $\mathrm{ED}_{50} 1 \mathrm{pmol} \mathrm{CS} / \mathrm{tube}$. The coefficient of variation for $\mathrm{ACTH}, \beta \mathrm{E}$, and CS RIA was $10.5 \pm 1.44,8.51 \pm 1.18$ and $15.33 \pm 2.34,(n=30)$, respectively.

Statistical evaluation. Inasmuch as the Bartlett test revealed no homoscedasticity between any of the experimental groups for any hormones, the nonparametric Kruskal-Wallis test with pairwise comparisons was applied using the Crunch statistical computer program. In the tables, the only differences between experimental groups of the same experiment (i.e. one dose in one time) are shown.

\section{RESULTS}

ACTH (Table 1). The mean plasma ir-ACTH levels of the untreated 30-d-old rats from the four experiments were higher than that of the untreated $10-\mathrm{d}$-old pups $(86.0 \pm 6.17 \mathrm{pmol} / \mathrm{L}$, $n=36$ versus $19.0 \pm 1.05 \mathrm{pmol} / \mathrm{L}, n=36 ; p<0.0001)$. Injection of $0.5 \mathrm{ng} / \mathrm{g} \mathrm{IL}-1 \beta$ to $10-\mathrm{d}$-old rats increased plasma ir-ACTH levels at $120 \mathrm{~min}$ but not at $30 \mathrm{~min}$ when compared with the saline-treated animals, whereas in the 30-d-old rats elevated hormone levels were seen at both times. Administration of $100 \mathrm{ng} / \mathrm{g} \mathrm{IL}-1 \beta$ produced significant increase of the plasma ir-ACTH level in both ages and in both time points tested. The relative elevation of plasma ir-ACTH after IL- $1 \beta$ was always higher in the prepubertal than in the infant rats when compared with the untreated rats. This tendency was also seen relative to the saline-treated group except for $30 \mathrm{~min}$ after the higher IL-1 $\beta$ dose $(100 \mathrm{ng} / \mathrm{g})$.

$\boldsymbol{\beta E}$ (Table 2). Similar differences to the ir-ACTH levels were seen in plasma ir- $\beta E$ levels of the untreated $10-$ and 30 -d-old rats $(52.7 \pm 2.76 \mathrm{pmol} / \mathrm{L}, n=36$ versus $96.5 \pm 8.85$ $\mathrm{pmol} / \mathrm{L}, n=36 ; p<0.0001)$. The lower dose of IL-1 $\beta(0.5$ $\mathrm{ng} / \mathrm{g}$ ) affected the ir- $\beta E$ levels neither in the 10 -d-old nor in the 30 -d-old rats $30 \mathrm{~min}$ after injection, whereas $120 \mathrm{~min}$ later significant elevation was seen only in the 10-d-old pups. Injection of $100 \mathrm{ng} / \mathrm{g}$ IL- $1 \beta$ elicited significant elevations in the plasma ir- $\beta E$ levels in rats of both age, the elevation being higher at $120 \mathrm{~min}$ than after $30 \mathrm{~min}$. The 120 -min increase in plasma ir- $\beta E$ relative to the saline-treated group was more pronounced in the 30 -d-old animals $(432 \%)$ than in the 10 -dold pups (251\%).

CS (Table 3). The difference between plasma CS levels of untreated 10- and 30-d-old rats exceeded that seen for irACTH, being about two orders of magnitude higher in the prepubertal than in the infant rats $(456.3 \pm 54.4 \mathrm{nmol} / \mathrm{L}, n=$ 36 versus $4.2 \pm 1.12 \mathrm{nmol} / \mathrm{L}, n=36 ; p<0.0001)$. In the 10 -d-old pups plasma ir-CS increased $120 \mathrm{~min}$ but not $30 \mathrm{~min}$ after $0.5 \mathrm{ng} / \mathrm{g}$ IL- $1 \beta$, whereas the high dose $(100 \mathrm{ng} / \mathrm{g})$ of IL- $1 \beta$ increased plasma ir-CS at both times. In the 30 -d-old rats 
Table 1. Effect of IL-1 10.5 or $100 \mathrm{ng} / \mathrm{g}$ body weight (b.w.) i.p.] on plasma ir-ACTH levels (pmol/L) of 10-day old and 30-day old rats

\begin{tabular}{|c|c|c|c|c|c|c|c|c|}
\hline \multirow{3}{*}{$\begin{array}{l}\mathrm{IL}-1 \beta \ldots \ldots \ldots \ldots \\
t_{\text {decap }} \ldots \ldots \ldots \ldots . . .\end{array}$} & \multicolumn{4}{|c|}{ 10-day old } & \multicolumn{4}{|c|}{ 30-day old } \\
\hline & \multicolumn{2}{|c|}{$0.5 \mathrm{ng} / \mathrm{g}$ b.w. } & \multicolumn{2}{|c|}{100 ng/g b.w. } & \multicolumn{2}{|c|}{$0.5 \mathrm{ng} / \mathrm{g}$ b.w. } & \multicolumn{2}{|c|}{100 ng/g b.w. } \\
\hline & $30 \mathrm{~min}$ & $120 \mathrm{~min}$ & $30 \mathrm{~min}$ & $120 \mathrm{~min}$ & $30 \mathrm{~min}$ & $120 \mathrm{~min}$ & $30 \mathrm{~min}$ & $120 \mathrm{~min}$ \\
\hline Untreated & $\begin{array}{c}18.9 \pm 3.03 \\
(8)\end{array}$ & $\begin{array}{c}14.2 \pm 0.73 \\
(10)\end{array}$ & $\begin{array}{c}22.5 \pm 1.85 \\
(8)\end{array}$ & $\begin{array}{c}21.2 \pm 1.71 \\
(10)\end{array}$ & $\begin{array}{c}90.2 \pm 10.64 \\
(9)\end{array}$ & $\begin{array}{c}96.9 \pm 14.26 \\
(9)\end{array}$ & $\begin{array}{c}60.0 \pm 5.58 \\
(9)\end{array}$ & $\begin{array}{c}96.9 \pm 14.26 \\
(9)\end{array}$ \\
\hline Saline & $\begin{array}{c}26.0 \pm 2.88^{u} \\
(8)\end{array}$ & $\begin{array}{c}21.2 \pm 3.70^{u} \\
(9)\end{array}$ & $\begin{array}{c}17.4 \pm 1.85 \\
(8)\end{array}$ & $\begin{array}{c}24.4 \pm 1.32 \\
(10)\end{array}$ & $\begin{array}{c}99.4 \pm 29.56 \\
(9)\end{array}$ & $\begin{array}{c}121.8 \pm 25.67 \\
(10)\end{array}$ & $\begin{array}{c}99.2 \pm 14.94 \\
(10)\end{array}$ & $\begin{array}{c}121.8 \pm 25.67 \\
(10)\end{array}$ \\
\hline $\mathrm{IL}$ & $\begin{array}{c}27.6 \pm 3.53^{u} \\
(8)\end{array}$ & $\begin{array}{c}40.1 \pm 7.38^{U, S} \\
(10)\end{array}$ & $\begin{array}{c}115.9 \pm 25.64^{U, S} \\
\text { (9) }\end{array}$ & $\begin{array}{c}216.3 \pm 22.15^{U, S} \\
(10)\end{array}$ & $\begin{array}{c}193.6 \pm 42.04^{s} \\
(9)\end{array}$ & $\begin{array}{c}302.2 \pm 75.83^{U, s} \\
(10)\end{array}$ & $\begin{array}{c}386.7 \pm 86.66^{U, s} \\
(10)\end{array}$ & $\begin{array}{c}2259.6 \pm 204.28^{U, S} \\
(10)\end{array}$ \\
\hline
\end{tabular}

Values are mean \pm SEM with number of determinations in parentheses; IL- $1 \beta$, the dose of IL-1 $\beta$ (ng/g b.w. i.p.); $t_{\text {decap }}$, the time between treatment and decapitation (min).

${ }^{u} p<0.05 ;{ }^{U} p<0.01$ compared with the corresponding untreated group.

${ }^{s} p<0.05 ;{ }^{s} p<0.01$ compared with the corresponding saline treated group.

Table 2. Effect of IL-1 10.5 or $100 \mathrm{ng} / \mathrm{g}$ body weight (b.w.) i.p.] on plasma ir- $\beta E$ levels (pmol/L) of 10-day old and 30-day old rats

\begin{tabular}{|c|c|c|c|c|c|c|c|c|}
\hline \multirow{3}{*}{$\begin{array}{l}\text { IL-1 } \beta \ldots \ldots \ldots \ldots \\
t_{\text {decap }} \ldots \ldots \ldots \ldots . . .\end{array}$} & \multicolumn{4}{|c|}{ 10-day old } & \multicolumn{4}{|c|}{ 30-day old } \\
\hline & \multicolumn{2}{|c|}{$0.5 \mathrm{ng} / \mathrm{g}$ b.w. } & \multicolumn{2}{|c|}{100 ng/g b.w. } & \multicolumn{2}{|c|}{$0.5 \mathrm{ng} / \mathrm{g}$ b.w. } & \multicolumn{2}{|c|}{100 ng/g b.w. } \\
\hline & $30 \mathrm{~min}$ & $120 \mathrm{~min}$ & $30 \mathrm{~min}$ & $120 \mathrm{~min}$ & $30 \mathrm{~min}$ & $120 \mathrm{~min}$ & $30 \mathrm{~min}$ & $120 \mathrm{~min}$ \\
\hline Untreated & $\begin{array}{c}33.4 \pm 2.15 \\
(8)\end{array}$ & $\begin{array}{c}52.8 \pm 5.62 \\
(10)\end{array}$ & $\begin{array}{c}58.9 \pm 4.19 \\
(8)\end{array}$ & $\begin{array}{c}63.0 \pm 3.57 \\
(10)\end{array}$ & $\begin{array}{c}104.6 \pm 21.22 \\
(9)\end{array}$ & $\begin{array}{c}98.1 \pm 18.90 \\
(9)\end{array}$ & $\begin{array}{c}85.5 \pm 13.56 \\
(9)\end{array}$ & $\begin{array}{c}98.0 \pm 18.89 \\
(9)\end{array}$ \\
\hline Saline & $\begin{array}{c}42.9 \pm 2.99 \\
(8)\end{array}$ & $\begin{array}{c}59.9 \pm 4.47 \\
(9)\end{array}$ & $\begin{array}{c}59.1 \pm 5.80 \\
(8)\end{array}$ & $\begin{array}{c}66.1 \pm 4.01 \\
(10)\end{array}$ & $\begin{array}{c}110.6 \pm 26.49 \\
(9)\end{array}$ & $\begin{array}{c}131.9 \pm 20.85 \\
(10)\end{array}$ & $\begin{array}{c}114.9 \pm 12.52 \\
(10)\end{array}$ & $\begin{array}{c}131.9 \pm 20.82 \\
(10)\end{array}$ \\
\hline $\mathrm{IL}$ & $\begin{array}{c}41.6 \pm 2.84 \\
(8)\end{array}$ & $\begin{array}{c}75.0 \pm 5.60^{U, s} \\
(10)\end{array}$ & $\begin{array}{c}104.3 \pm 13.16^{U, S} \\
(9)\end{array}$ & $\begin{array}{c}165.9 \pm 13.31^{U, S} \\
(10)\end{array}$ & $\begin{array}{c}133.8 \pm 18.84 \\
(9)\end{array}$ & $\begin{array}{c}165.7 \pm 39.53 \\
(10)\end{array}$ & $\begin{array}{c}243.5 \pm 40.92^{U, s} \\
(10)\end{array}$ & $\begin{array}{c}569.3 \pm 30.56^{\text {U.S }} \\
(10)\end{array}$ \\
\hline
\end{tabular}

Values are mean \pm SEM with number of determinations in parentheses; IL-1 $\beta$, the dose of IL-1 $\beta$ (ng/g b.w. i.p.); $t_{\text {decap }}$, the time between treatment and decapitation (min).

${ }^{U} p<0.01$ compared with the corresponding untreated group.

${ }^{s} p<0.05 ;{ }^{s} p<0.01$ compared with the corresponding saline treated group. 


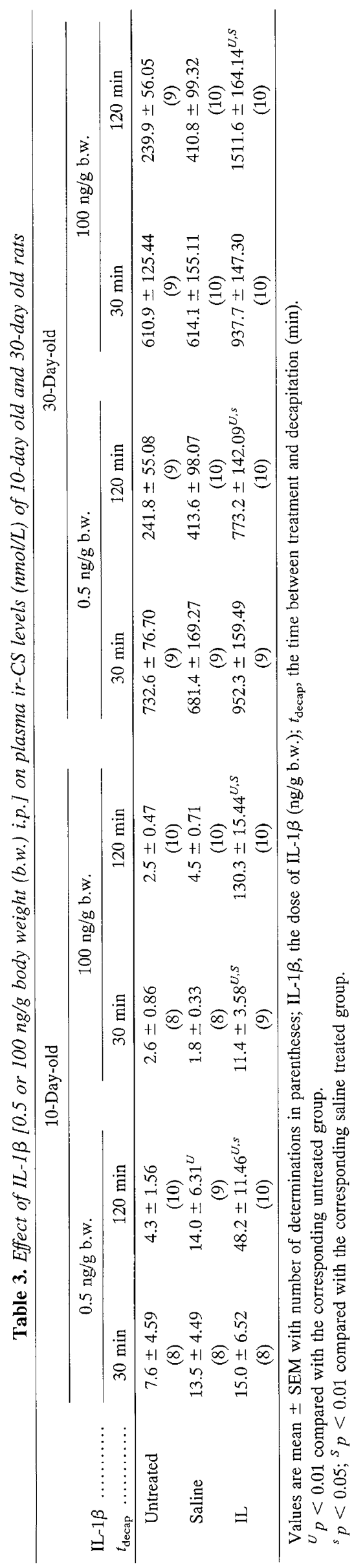

plasma CS levels were elevated only $120 \mathrm{~min}$ after injection of 0.5 or $100 \mathrm{ng} / \mathrm{g} \mathrm{IL}-1 \beta$.

\section{DISCUSSION}

In the present work, plasma ir-ACTH, ir- $\beta \mathrm{E}$, and ir-CS levels were measured in the 10- (infant) and 30-d-old (prepubertal) rats after i.p. injection of IL-1 $\beta$. When comparing the basal hormone levels of the 10- and the 30-d-old rats, the levels of ir-ACTH (Table 1) and of ir- $\beta E$ levels (Table 2 ) were higher in the prepubertal than in the infant rats. For the ir-CS levels this difference was more striking (Table 3), although the plasma ir-ACTH concentrations of the same rats did not reflect stressed values $(86.0 \pm 6.17 \mathrm{pmol} / \mathrm{L})$. This could be explained by the enhanced sensitivity of the adrenal gland of the prepubertal rats to the circulating ACTH or to experimental manipulations. This is in agreement with previous findings when ir- $\beta E(20)$ and ir-CS $(20,25)$ concentrations in the plasma of the 10- and 22-d-old rats were compared. Inasmuch as we paid special attention to keeping maternal deprivation very short (maximum $30 \mathrm{~s}$ ) during the experiment, the ir-CS levels of the infant rats were very low, reflecting the basal activity of the HPAA (Table 3). There was a tendency for slightly elevated hormone levels after i.p. saline injection, but significant change was seen only in few cases.

Elevation in plasma ir-ACTH levels after the low dose of IL-1 $\beta(0.5 \mathrm{ng} / \mathrm{g})$ at $30 \mathrm{~min}$ was seen only in the 30 -d-old rats. The rise in plasma ir-ACTH levels 120 min after the injection of $0.5 \mathrm{ng} / \mathrm{g} \mathrm{IL}-1 \beta$ was comparable in the 10 -d-old pups and in the 30 -d-old rats (189 and $248 \%$, respectively). Interestingly, $30 \mathrm{~min}$ after injection of the higher dose of IL-1 $\beta(100 \mathrm{ng} / \mathrm{g})$, the relative increase in plasma ACTH level was higher in the 10 - than in the 30-d-old rats (666 versus 380\%), although higher absolute values were seen in the latter group. In contrast, $120 \mathrm{~min}$ after the injection a larger increase was seen in the prepubertal than in the infant rats (1855 versus 866\%). These findings are in contrast with those of Witek-Janusek (25) who by injecting a $90 \%$ lethal dose of endotoxin found no difference in basal and stimulated plasma ACTH levels of the 10- and 21-d-old rats. It is known that the activation of HPAA by endotoxins is mediated by cytokines such as IL-1, tumor necrosis factor- $\alpha$, and IL- 6 , which are released from immunoreactive cells and affect the brain (for review, see Ref. 26). It may be supposed that the complexity of the reaction to endotoxin is fully developed by $\mathrm{d} 10$, but the maturation of the sensitivity of the HPAA to IL- $1 \beta$ is delayed.

In the 10-d-old rats changes in plasma ir- $\beta E$ levels showed similar pattern to that seen for ir-ACTH after both dose of IL- $1 \beta$, but the relative ir- $\beta$ E increase was generally smaller than that of the ir- $\mathrm{ACTH}$, especially at $120 \mathrm{~min}$. These differences were more expressed in the 30-d-old rats, as only the high (100 ng/g) dose of IL- $1 \beta$ affected plasma ir- $\beta$ E levels.

Changes in the plasma ir-CS concentrations in the 10-d-old rats resembled that of the ir-ACTH levels, but the 120-min relative increase was considerably higher than for ir-ACTH. In contrast, in the 30-d-old rats plasma ir-CS was not elevated every time when ir-ACTH was high (i.e. 30 min after IL-1 $\beta$ ) and the relative increase for ir-CS $120 \mathrm{~min}$ after $100 \mathrm{ng} / \mathrm{g}$ 
IL-1 $\beta$ was lower than for ir-ACTH. These results indicate a more susceptible adrenal response of the infant rats to IL-1 $\beta$. This again could be an indication of the higher responsiveness of the adrenal either to the circulating ir-ACTH or to the possible direct effect of IL- $1 \beta$ on the adrenal hormone secretion (15).

Earlier studies reported dose- and time-related elevations in plasma ACTH, CS, and catecholamine concentrations after i.v. as well as intracerebroventricular IL-1 $\beta$ administration in adult rats $(8-10)$. IL- $1 \beta$ is believed to stimulate either directly or indirectly the secretion of hypothalamic CRH (11-13) known to predominate in the control of pituitary corticotrophs. Intrahypothalamic IL- $1 \beta$ infusion as well as microlesions in the rat brain demonstrated the importance of certain brain structures (organum vasculosum of lamina terminalis, preoptic area, paraventricular nucleus) in the IL-induced stimulation of the HPAA $(27,28)$. Certain neurones in the preoptic nucleus have receptors to which the cytokines bind (for review, see Ref. 26). The preoptic neurones communicate with another hypothalamic nucleus, the paraventricular nucleus, which contains neurones that release $\mathrm{CRH}$.

When injected i.v., $0.5 \mathrm{ng} / \mathrm{g} \mathrm{IL}-1 \beta$ produced an extremely high plasma ACTH response in adult rats 15 min after administration (10). In our hands i.p. injection of the same dose had no effect on ir-ACTH and on ir- $\beta E$ levels in the infant rat at 30 min and on the ir- $\beta E$ level of the prepubertal rats at 30 and 120 min. This may indicate the different absorption time of the i.v. and of i.p. administered IL- $1 \beta$ and/or changes in time course of the hypothalamo-pituitary activation during postnatal development. Additionally, in the 10 -d-old rats the relative elevation of ir- $\beta$ E levels after $0.5 \mathrm{ng} / \mathrm{g}$ IL- $1 \beta$ did not approximate the level that we have seen after a moderate stimulus of an opiate anesthetic (21). Therefore we administered $100 \mathrm{ng} / \mathrm{g}$ IL- $1 \beta$ to another group of rats, but the relative ir- $\beta \mathrm{E}$ elevation induced by this higher dose still remained below the elevation that could be elicited by the opiate narcotic (21). Thus, even the higher IL-1 $\beta$ dose can be considered as a submaximal stimulus of ir- $\beta \mathrm{E}$ secretion.

The circulating ir- $\beta E$ originates from both the anterior and intermediate lobe of the pituitary gland. The control of the ir- $\beta E$ secretion from the anterior lobe is similar to that of the $\mathrm{ACTH}$; CRH-stimulated release of ir-ACTH and ir- $\beta \mathrm{E}$ from the anterior pituitary depicts parallel dose-response curves (29). The secretory activity of the melanotrophs in the intermediate lobe is predominantly under the tonic inhibition of the hypothalamic dopaminergic system (30). Administration of IL-1 $\beta$ affected plasma ir- $\beta$ E levels less than ir-ACTH concentrations (Tables 1 and 2). Our $\beta E$ antibody shows relatively low cross-reaction with $\beta$-lipotropin $(30 \%)$ and other $\beta E$ related peptides, thus it measures predominantly the secretory activity of the intermediate lobe $(21,24)$. The finding that the relative changes in ir- $\beta \mathrm{E}$ plasma levels were less than that of the ir-ACTH may reflect the different response of the corticotrophs in the anterior pituitary and of the melanotrophs in the intermediate pituitary to the exogenous IL- $1 \beta$ in the infant and prepubertal rats.

As discussed above, IL-1 $\beta$ exerts a complex effect (hypothalamic, extrahypothalamic, pituitary, and adrenal) on the
HPAA of the adult rat, but its effect in the infant rat has not been studied before. The finding that the changes in plasma ACTH levels were more pronounced in the 30- than in the 10 -d-old rats (Table 1) may indicate that in infant rats the pituitary ACTH secretory response to IL- $1 \beta$ is weaker compared with the reactivity in later age. This finding could be explained by the stress-hyporesponsive state of these animals, by the different kinetics of the HPAA activation in the infant and in the adult rats, or by a specific neuroendocrine effect of IL-1 $\beta$. IL-1 $\beta$ administration-induced relative changes in plasma CS levels were more pronounced in the 10 - than in the 30-d-old rats. This finding together with the distinct pattern of ir-ACTH and of ir- $\beta \mathrm{E}$ changes may indicate that, in the infant and in the prepubertal rats, IL- $1 \beta$ activates the HPAA as a specific, receptor-mediated stimulus and not by eliciting a nonspecific stress reaction.

\section{REFERENCES}

1. Dinarello CA 1988 Biology of interleukin 1. FASEB J 2:108-115

2. Dinarello CA, Mier JW 1987 Lymphokines. N Engl J Med 317:940-945

3. Bernton EW, Beach JE, Holaday JW, Smallridge RC, Fein HG 1987 Release of multiple hormones by direct action of interleukin 1 on pituitary cell. Science 233:519-521

4. Besedovsky H, Del Rey A, Sorkin E, Dinarello CA 1986 Immunoregulatory feedback between interleukin-1 and glucocorticoid hormones. Science, 233:652-654

5. Rettori V, Jurcovicova J, McCann SM 1987 Central action of interleukin-1 altering the release of TSH, growth hormone, and prolactin in the male rat. $J$ Neurosci Res $18: 522-524$

6. Weigent DA, Blalock JE 1987 Interactions between the neuroendocrine and immune systems common hormones and receptors. Immunol Rev 100:79-108

7. Nakatsuru K, Ohgo S, Oki Y, Matsukura S 1991 Interleukin-1 (IL-1) stimulates arginin vasopressin (AVP) release from superfused rat hypothalamo-neurohypophyseal complexes independently of cholinergic mechanism. Brain Res 554:38-45

8. Uehara A, Gottschall PE, Dahl RR, Arimura A 1987 Stimulation of ACTH release by human interleukin-1 $\beta$, but not by interleukin $-1 \alpha$, in conscious, freely moving rats. Biochem Biophys Res Commun 146:1286-1290

9. Weidenfeld J, Abramsky O, Ovadia H 1989 Effect of interleukin-1 on ACTH and corticosterone secretion in dexamethasone and adrenalectomized pretreated male rats. Neuroendocrinology 50:650-654

10. Rivier C, Vale W, Brown M 1989 In the rat, Interleukin- $1 \alpha$ and $-\beta$ stimulate adrenocorticotropin and catecholamine release. Endocrinology 125:3096-3120

11. Sapolsky R, Rivier C, Yamamoto G 1987 Interleukin-1 stimulates the secretion of hypothalamic corticotropin-releasing factor. Science 238:522-524

12. Uehara A, Gottschall PE, Dahl R, Arimura A 1987 Interleukin-1 stimulates ACTH release by an indirect action which requires endogenous corticotropin releasing factor. Endocrinology 121:1580-1582

13. Lyson K, McCann SM 1993 Alpha-melanocyte-stimulating hormone abolishes IL-1and IL-6-induced corticotropin-releasing factor release from the hypothalamus in vitro. Neuroendocrinology 58:191-195

14. Cambronero JC, Rivas FJ, Borell J, Guaza C 1992 Interleukin-1-beta induces pituitary adrenocorticotropin secretion: evidence for glucocorticoid modulation. Neuroendocrinology 55:648-654

15. Andreis PG, Neri G, Belloni AS, Mazzocchi G, Kasprzak A, Nussdorfer GG 1991 Interleukin- $1 \beta$ enhances corticosterone secretion by acting directly on the rat adrenal gland. Endocrinology 129:53-57

16. Vazquez DM, Akil H 1993 Pituitary-adrenal response to ether vapour in the weanling animal: characterization of the inhibitory effect of glucocorticoids on adrenocorticotropin secretion. Pediatr Res 34:646-653

17. Walker CD, Perin M, Vale W, Rivier C 1986 Ontogeny of the stress response in the rat: role of the pituitary and the hypothalamus. Endocrinology 118:1445-1451

18. Arai M, Widmaier EP 1991 Activation of the pituitary-adrenocortical axis in day old rats by insulin-induced hypoglycemia Endocrinology 129:1505-1512

19. Walker CD, Scribner KA, Cascio CS, Dallman MF 1991 The pituitary-adrenocortical system of neonatal rats is responsive to stress throughout development in a timedependent and stressor-specific fashion. Endocrinology 128:1385-1395

20. Angelogianni $\mathrm{P}$, Gianoulakis $\mathrm{C} 1989$ Ontogeny of the $\beta$-endorphin response to stress in the rat: role of the pituitary and the hypothalamus. Neuroendocrinology 50:372381

21. Barna I, Åcs Zs, Koenig JI 1993 Effects of hypnorm (Fentanyl) on the ACTH/ $\beta$ endorphin levels in plasma, pituitary and brain of 10-day old rat. Life Sci 52:14171424

22. Rivier C 1994 Stimulatory effect of interleukin- $1 \beta$ on the hypothalamic-pituitaryadrenal axis of the rat: influence of age, gender and circulating sex steroids. J. Endocrinol 140:365-372

23. Wingfield P, Payton M, Tavernier J, Barnes M, Shaw A, Rose K, Simona MG, Demczuk S, Williamson K, Dayer JM 1986 Purification and characteriza- 
tion of human interleukin-1 $\beta$ expressed in recombinant $E$. coli. Eur J Biochem 160:491-497

24. Barna I, Koenig JI 1992 Effects of mediobasal hypothalamic lesion on immunoreactive $\mathrm{ACTH} / \beta$-endorphin levels in cerebrospinal fluid, in discrete brain region, in plasma, and in pituitary of the rat. Brain Res 593:69-76

25. Witek-Janusek L 1988 Pituitary-adrenal response to bacterial endotoxin in developing rats Am J Physiol 255:E525-E530

26. Black PH 1994 Immune system-central nervous system interactions: effect and immunomodulatory consequences of immune system mediators of the brain. Antimicrob Agents Chemother 38:7-12

27. Katsuura G, Arimura A, Koves K, Gottschall PE 1990 Involvement of organum vasculosum of lamina terminalis and preoptic area in interleukin $1 \beta$-induced $\mathrm{ACTH}$ release. Am J Physiol 258:E163-E171

28. Barbanel G, Ixart G, Szafarczyk A, Malaval F, Assenmacher I 1990 Intrahypothalamic infusion of interleukin- $1 \beta$ increases the release of corticotropin-releasing hormone (CRH 41) and adrenocorticotropic hormone (ACTH) in free-moving rats bearing a push-pull cannula in the median eminence. Brain Res 516:31-36

29. Young E, Akil H 1985 Changes in releasability of ACTH and $\beta$-endorphin with chronic stress. Neuropeptides 5:545-548

30. Höllt V, Bergmann M 1982 Effects of acute and chronic haloperidol treatment on the concentrations of immunoreactive $\beta$-endorphin in plasma pituitary and brain of rats. Neuropharmacology 21:147-157 